\title{
Influence of allochthonous matter on microbial community structure and function in an upwelling system off the northwest Iberian Peninsula
}

\author{
Eva Teira*, María Aranguren-Gassis, Jose González, Sandra Martínez-García, \\ Patricia Pérez, Pablo Serret
}

Departamento de Ecoloxía e Bioloxía Animal, Universidade de Vigo, Campus Lagoas-Marcosende, 36310 Vigo, Spain

\begin{abstract}
The input of allochthonous matter of continental origin to coastal zones globally may cause changes in the activity (function) as well as the taxonomic composition (structure) of the microbial plankton community. The goal of the present study was the simultaneous analysis of microbial plankton community structure (size-fractionated phytoplankton biomass, bacterial community composition) and function (particulate and dissolved primary production, bacterial production, microbial plankton community respiration) in the northwest Iberian coastal transition zone during a dry (February 2005) and a rainy (October 2005) period. An influence of freshwater input was observed in October, even at an offshore site, but not in February. We found an autotrophic community dominated by picophytoplankton during both sampling periods. In contrast, the bacterial groups Beta- and Gammaproteobacteria were significantly more abundant during the high precipitation period. Primary production rates were low and similar during both sampling periods; however, bacterial production was 8-fold and community respiration was 3-fold higher in October than in February. Consequently, the microbial community metabolism was net autotrophic in February and net heterotrophic in October. The high precipitation and the significant presence of bacteria belonging to the Betaproteobacteria, typical for freshwater systems, in October compared to February, strongly suggest an influence of material of continental origin on microbial metabolism in this coastal transition zone.
\end{abstract}

KEY WORDS: Microbial plankton structure · Primary production · Bacterial production · Respiration · Allochthonous matter $\cdot$ NW Iberian Peninsula

\section{INTRODUCTION}

Carbon and nutrient cycles in ocean margins are influenced by the input of inorganic and organic nutrients from adjacent land, ocean and from the atmosphere. In the global coastal zone, $70 \%$ of the nitrogen input comes from the ocean, $22 \%$ from continents and $8 \%$ from the atmosphere (Wollast 1993).

The discharge of freshwater from river outflows is of considerable relevance in coastal zones (Álvarez et al. 2006). The significant input of carbon and energy to coastal ecosystems may force carbon flow toward the heterotrophic and microbial part of the food web (Sandberg et al. 2004). Growing evidence indicates that the input of allochthonous, land-derived material plays a relevant role in sustaining aquatic metabolism in marine systems (Duarte \& Prairie 2005). The input of allochthonous matter of continental origin may cause changes in the activity (function) as well as the taxonomic composition (structure) of the microbial plankton community. Riverine bacterioplankton successfully immigrates in seawater (Langenheder et al. 2004, Kisand et al. 2005), growing at rates similar to those in freshwater. The Betaproteobacteria, which are abundant in freshwater systems but nearly absent from the marine environment (Methé et al. 1998), have been considered as a tracer of terrigenous matter input in coastal studies (Hobbie 1988).

The northwest Iberian coastal transition zone is an area affected by a marked seasonal cycle of coastal winds (Nogueira et al. 1997). The annual cycle is divided into an upwelling season from April to Sep- 
tember (northerly winds prevail) with short relaxation intervals that enhance productivity (Álvarez-Salgado et al. 2002) and a downwelling season (from October to March, southerly winds prevail), which is characterized by low phytoplankton biomass and primary production. River discharge and continental runoff is highest during this low productivity period (Pérez et al. 1992), which creates a low salinity water plume that extends along the shore (Varela et al. 2005). When wind relaxes or turns to northerly winds the plume is exported offshore. Since this pattern is also present on the Portuguese shelf, Peliz et al. (2002) proposed to name it Western Iberia Buoyant Plume (WIBP). This buoyancy lens of 'low' salinity $(<35.8)$ water at the surface to about $25 \mathrm{~m}$ water depth can stretch out as far as the $1000 \mathrm{~m}$ isobath.

Another common feature of the region is the Iberian Poleward Current system (IPCs). The IPCs shows up as a core of high temperature and salinity water in the coastal transition zone (CTZ) of the northwest Iberian Peninsula. It can be easily traced in a vertical section by conspicuous maxima of salinity ( $>35.85$ ) and temperature $\left(>14^{\circ} \mathrm{C}\right)$ from the surface to $\sim 150 \mathrm{~m}$ depth (Álvarez-Salgado et al. 2003).

The frontal zone in the northwest Iberian CTZ resulting from the interaction between the WIBP and the IPCs domains has been well described during the downwelling season; however, very limited information exists on its biological consequences at the level of the microbial plankton community (Castro et al. 1997, Teira et al. 2001, Morán et al. 2002). Teira et al. (2001) found a net heterotrophic metabolism in shelf/shelfbreak waters, associated with high community respiration rates, picoplankton dominated communities, and high relative rates of dissolved organic carbon (DOC) production in October 1999. However, all of these studies were conducted during a single sampling period within the low productivity season (September-October), and none of them investigated the structure and activity of phytoplankton and bacteria along with rates of microbial community respiration.

Within this context, we hypothesize that the input of material of continental origin must have an effect on both the structure and functioning of the microbial plankton community. To test our hypothesis, we examined the microbial plankton community structure (sizefractionated phytoplankton biomass, bacterial community composition) and function (particulate and dissolved primary production, bacterial production, microbial community respiration) under contrasting scenarios in terms of allochthonous matter loading in the CTZ of the northwest Iberian Peninsula during the low productivity season. We sampled during a dry (February 2005) and a rainy period (October 2005) in order to investigate these distinct situations.

\section{MATERIALS AND METHODS}

Sampling area. The CTZ of the northwest Iberian Peninsula was sampled during 2 cruises conducted from 7 to 14 February and from 23 to 30 October 2005 on board RV 'Cornide de Saavedra'. The sampling stations are represented in Fig. 1. In February, we sampled along a latitudinal transect centered at $41.92^{\circ} \mathrm{N}$, close to the mouth of the river Miño. We could not complete this transect during October due to very bad weather conditions. A total of 5 to 6 stations were occupied during each cruise. Temperature, salinity and irradiance profiles were obtained with a SBE9/11 CTD attached to a rosette sampler equipped with twenty-four 121 Niskin bottles. CTD temperature and salinity sensors were factory-calibrated using digital reversing thermometers and water samples drawn for salinity determination.

At each station, we took samples at 5 depths within the euphotic zone (defined as the depth reached by $1 \%$ of surface irradiance) in order to measure sizefractionated chlorophyll a (chl a) concentration, prokaryotic abundance, bacterial production, and to study the taxonomic composition of the bacterial community using a fluorescence in situ hybridization (FISH) technique. At 5 out of 11 stations in both the coastal and open ocean zone, we also determined particulate and dissolved primary production and microbial community respiration in order to construct in vitro $\mathrm{C}$ budgets.

Meteorological variables. Daily offshore Ekman transport values $\left(-\mathrm{Qx}, \mathrm{m}^{3} \mathrm{~s}^{-1} \mathrm{~km}^{-1}\right)$ were calculated as described by Nieto-Cid et al. (2004). Positive and negative Ekman transport values indicate upwelling and downwelling situations, respectively. Precipitation data $(\mathrm{mm})$ were obtained from the hydrological bulletin of the Spanish Ministerio de Medio Ambiente. The river Oitabén-Verdugo, the main tributary to the Ría de Vigo, is a combination of regulated and natural

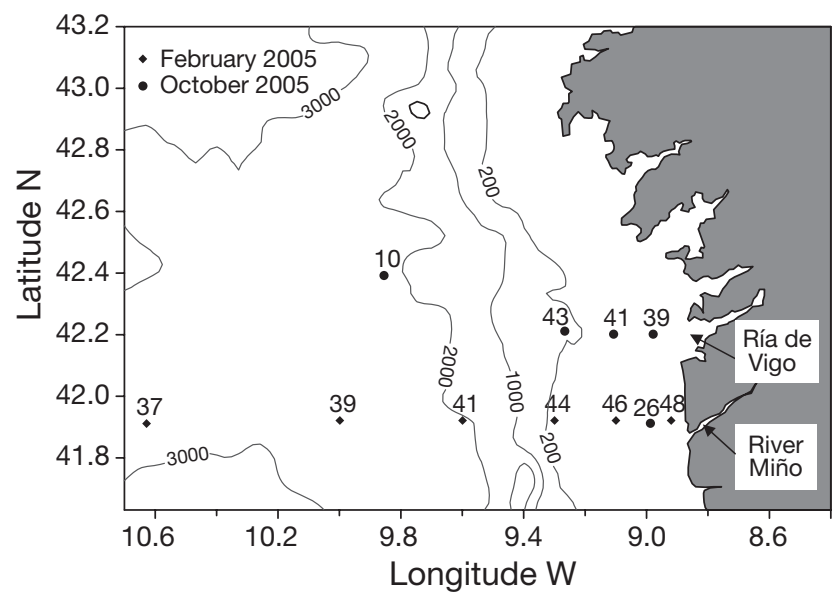

Fig. 1. Locations of the stations sampled during the cruises conducted in February and October 2005 
flows. The flow from the Eiras reservoir was provided by the company in charge of the management of urban waters (Seraguas SA), and the natural component of the flow was calculated from the daily precipitation in the drainage basin according to the empirical equation of Ríos et al. (1992).

Size-fractionated chl a concentration. Size-fractionated chl a was measured fluorometrically after concentration of particulate matter by filtering $250 \mathrm{~cm}^{3}$ of seawater through 5 and $0.2 \mu \mathrm{m}$ pore size polycarbonate filters. The filters were immediately frozen and kept at $-20^{\circ} \mathrm{C}$ until further analysis ashore. In the laboratory, chl a was extracted by adding $5 \mathrm{~cm}^{3}$ of $90 \%$ acetone to the filters. Extraction was done at $4^{\circ} \mathrm{C}$ overnight. Chl a fluorescence was determined with a TD700 fluorometer calibrated with pure chl a (from spinach, Sigma). Chl a was converted to phytoplankton biomass (PB) using a conservative C:chl a ratio of 50 (Longhurst 1995, Barlow et al. 1998).

Bacterial biomass (BB) and bacterial community composition. Immediately after collecting the samples from the Niskin bottles, water samples of 5 to $10 \mathrm{~cm}^{3}$ were fixed by adding $0.2 \mu \mathrm{m}$ filtered paraformaldehyde ( $2 \%$ final conc.) and stored at $4{ }^{\circ} \mathrm{C}$ in the dark for 4 to $12 \mathrm{~h}$. Thereafter, the sample was filtered through a $0.2 \mu \mathrm{m}$ pore size polycarbonate filter (Millipore, GTTP, $25 \mathrm{~mm}$ diameter) supported by a cellulose nitrate filter (Millipore, HAWP, $0.45 \mu \mathrm{m}$ pore size), washed twice with Milli-Q water, dried and stored in a microfuge vial at $-20^{\circ} \mathrm{C}$ until further processing in the laboratory.

Filters for catalyzed reporter deposition (CARD)FISH were embedded in low-gelling-point agarose and incubated with lysozyme. Filters were cut into sections and hybridized with horseradish peroxidase (HRP)-labeled oligonucleotide probes (ALF968 for Alphaproteobacteria, GAM42a for Gammaproteobacteria, BET42a for Betaproteobacteria, CF319a for Bacteroidetes, EUB338 for Bacteria, and NON-EUB338, as negative control) and tyramide-Alexa488 for signal amplification following the protocol described in Teira et al. (2008). Non-fluorescent competitor probes were used in equal amounts with probes BET42a and GAM42a to obtain optimal stringency conditions. BET42a and GAM42a served as competitors for each other. It is important to mention that the FISH probe used for Bacteroidetes (CF319a) targets mainly the class Flavobacteria (formerly known as Cytophagales), which comprises the most abundant class of planktonic marine Bacteroidetes (Alonso et al. 2007). Cells were counter-stained with a 4',6-diamidino-2phenylindole (DAPI)-mix consisting of 5.5 parts of Citifluor (Citifluor) and 1 part of Vectashield (Vector Laboratories), and 0.5 parts of phosphate buffered saline (PBS) with DAPI (final concentration $1 \mu \mathrm{g}$ $\left.\mathrm{cm}^{-3}\right)$.
The slides were examined under a Leika microscope equipped with a 100W Hg-lamp and filter sets for DAPI and Alexa488. More than 800 DAPI-stained cells were counted per sample. For each microscope field, 3 different categories were enumerated: (1) total DAPIstained cells, (2) cells stained with a specific probe, and (3) Synechococcus cells. Negative control counts (hybridization with HRP-NON338) were always below $0.5 \%$ of DAPI-stained cells. The counting error, expressed as the percentage of the standard error (SE) between replicates $(\mathrm{SE} / \mathrm{MEAN} \times 100)$, was $<2 \%$ for DAPI-counts and $<9 \%$ for FISH counts. This percentage was higher for Betaproteobacteria (25\%). Given that Archaea are not abundant in the surface layer of most marine environments, comprising $<2 \%$ of total DAPI-counts (e.g. Alderkamp et al 2006), DAPI-counts will hereafter be referred to as bacterial abundance. $\mathrm{BB}$ was estimated using a conversion factor of $12 \mathrm{fg} \mathrm{C}$ $\mathrm{cell}^{-1}$ (Fukuda et al. 1998). For Synechococcus biomass,

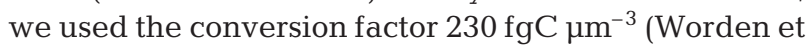
al. 2004), and a mean cell radius of $0.55 \mu \mathrm{m}$.

Bacterial production (BP) and bacterial respiration (BR). BP (encompassing bulk prokaryotic production) was measured by incubating 5 to $10 \mathrm{~cm}^{3}$ of seawater in duplicate and 1 formaldehyde-killed blank with 40 (1Hot:9Cold) nmol l-1 $\left[{ }^{3} \mathrm{H}\right]$-leucine (final conc. SA 5957 and $5587 \mathrm{GBq} \mathrm{mmol}^{-1}$, Amersham) in the dark at in situ $\left( \pm 1^{\circ} \mathrm{C}\right)$ temperature for 1 to $1.5 \mathrm{~h}$. Thereafter, the incubation was terminated by adding formaldehyde ( $2 \%$ final conc.) to the samples and filtering them through $0.2 \mu \mathrm{m}$ cellulose nitrate filters (Millipore, $25 \mathrm{~mm}$ diameter). Subsequently, the filters were rinsed $3 \times$ with $5 \%$ ice-cold trichloroacetic acid, placed in scintillation vials and stored at $-20^{\circ} \mathrm{C}$ until counting in a liquid scintillation counter. A multipurpose liquid scintillation cocktail was used (Insta-Gel plus, Perkin Elmer). The disintegrations per minute (DPM) of the formaldehyde-fixed blank were subtracted from the samples and the resulting DPM converted into leucine incorporation rates.

Two experiments, 1 with coastal and 1 with oceanic water, were conducted in order to determine the saturation leucine concentration, and 2 dilution experiments, 1 during each cruise, were performed in order to determine the leucine-to-carbon conversion factor. Samples from a shelf station (Stn 46 in February and Stn 26 in October) were prefiltered through a $0.8 \mu \mathrm{m}$ pore size polycarbonate filter to remove protozoan grazers, diluted (1:5) with $0.2 \mu \mathrm{m}$-filtered water from the same location, and kept in 11 acid-cleaned glass bottles in the dark at in situ temperature $\left( \pm 1^{\circ} \mathrm{C}\right)$.

Subsamples for estimating BP and BB were taken at intervals of $12 \mathrm{~h}$ until bacteria reached the stationary growth phase ( 3 to $4 \mathrm{~d}$ ). Leucine-to-carbon conversion factors were estimated using the cumulative method 
(Bjørnsen \& Kuparinen 1991). The obtained conversion factors were 2.34 and $2.03 \mathrm{~kg} \mathrm{C} \mathrm{mol} \mathrm{Leu^{-1 }}$ in February and October, respectively. BR (mmol $\left.\mathrm{C} \mathrm{m}^{-3} \mathrm{~d}^{-1}\right)$ was estimated from BP using the model $\left(\mathrm{BR}=3.69 \mathrm{BP}^{0.58}, \mathrm{r}^{2}\right.$ $=0.56, \mathrm{n}=286$ ) by Robinson (2008). Estimates of bacterial carbon demand (BCD) were obtained by summing up measured BP and estimated BR.

Primary production. Particulate and dissolved primary production rates (PPP and DPP, respectively) were measured at selected stations. For the measurement of PPP, four $75 \mathrm{~cm}^{3}$ acid-cleaned bottles (3 transparent and 1 dark bottles, Corning) were filled with seawater from 5 depths with surface irradiance levels ranging from 70 to $1 \%$. Bottles were inoculated with $360 \mathrm{kBq}(10 \mu \mathrm{Ci})$ of $\mathrm{NaH}^{14} \mathrm{CO}_{3}$ and then incubated for 2 to $3 \mathrm{~h}$ in an on-deck incubator covered with a combination of nets simulating the light field (monitored using a spherical PAR sensor) experienced by the cells at the original sampling depths. The bottles were kept refrigerated by circulating sea surface water. After the incubation period, samples were filtered at very low vacuum pressure $(<50 \mathrm{~mm} \mathrm{Hg})$ through $0.2 \mu \mathrm{m}$ pore size polycarbonate filters. Filters were decontaminated by exposing them to fumes of concentrated $\mathrm{HCl}$ for 12 h. For DPP production, 3 light and 2 dark acidwashed glass bottles $\left(36 \mathrm{~cm}^{3}\right.$, Pyrex) were filled with seawater and spiked with $555 \mathrm{kBq}(15 \mu \mathrm{Ci}) \mathrm{NaH}^{14} \mathrm{CO}_{3}$ following the methodology described in Marañón et al. (2004). The procedure is essentially the same as in Teira et al (2001), except that blank tests are substituted by dark bottle incubations. Incubations for DPP lasted 2 to $3 \mathrm{~h}$ and were done in the same incubation system as for PPP. Radioactivity was determined by liquid scintillation counting ashore. A multipurpose liquid scintillation cocktail was used for both filters and filtrates (Insta-Gel plus, Perkin Elmer). Quenching corrections were made using an external standard. Total primary production for the construction of carbon budgets was obtained as the sum of PPP and DPP.

Microbial plankton community respiration. Oxygen consumption rates were determined by dark-bottle incubations at 4 selected depths. Eight dark, $125 \mathrm{~cm}^{3}$, gravimetrically calibrated borosilicate bottles were carefully filled from each depth using silicone tubing, overflowing $>250 \mathrm{~cm}^{3}$. An initial set of 4 dark bottles was fixed immediately for initial oxygen concentration, the remainder being kept in the dark for $24 \mathrm{~h}$ in the same incubator as for ${ }^{14} \mathrm{C}$-incubations. Fixing and storage procedures, reagents and standardisation followed the recommendations of Grasshoff et al.
(1983). Dissolved oxygen (DO) concentration was measured by automated precision Winkler titration performed with a Metrohm 721 DMS Titrino using a potentiometric end point detector as described in Serret et al. (1999). To be able to compare values with previous studies, microbial plankton community respiration (CR) was converted into carbon equivalents by using a respiration quotient (RQ) of 1 (Robinson 2008).

Euphotic zone integration. Euphotic zone-integrated values of $\mathrm{PB}, \mathrm{PPP}, \mathrm{DPP}, \mathrm{BB}, \mathrm{BP}, \mathrm{BCD}$, and $\mathrm{CR}$ were obtained by trapezoidal integration of the volumetric data down to the depth of $1 \%$ surface irradiance. Euphotic zone depth ranged from $45 \mathrm{~m}$ at near shore stations to $100 \mathrm{~m}$ in offshore waters.

\section{RESULTS}

\section{Meteorological conditions}

The annual cycle of the offshore Ekman transport and precipitation is represented in Fig. 2. The February cruise took place mainly under relaxed winds (average $-\mathrm{Qx}=149 \mathrm{~m}^{3} \mathrm{~s}^{-1} \mathrm{~km}^{-1}$ from 7 to 12 February) and ended with upwelling-favourable winds (average -Qx $=1067 \mathrm{~m}^{3} \mathrm{~s}^{-1} \mathrm{~km}^{-1}$ from 13 to 14 February), whereas the October cruise took place during downwelling conditions (average $-\mathrm{Qx}=-2036 \mathrm{~m}^{3} \mathrm{~s}^{-1} \mathrm{~km}^{-1}$ ). There was a period of northerly/relaxed winds (average - Qx $=-138 \mathrm{~m}^{3} \mathrm{~s}^{-1} \mathrm{~km}^{-1}$ ) during the $10 \mathrm{~d}$ previous to the October cruise. Rainfall was abnormally low, almost zero, during the February cruise, and extremely high in October, about twice the historical monthly mean for the region, which would imply enhanced freshwater runoff. The measured flow from the river Oitabén-Verdugo (the main river discharging within the Ría de Vigo) was, on average, $5 \mathrm{~m}^{3} \mathrm{~s}^{-1}$ during the February cruise, and $27.9 \mathrm{~m}^{3} \mathrm{~s}^{-1}$ during the October cruise. In

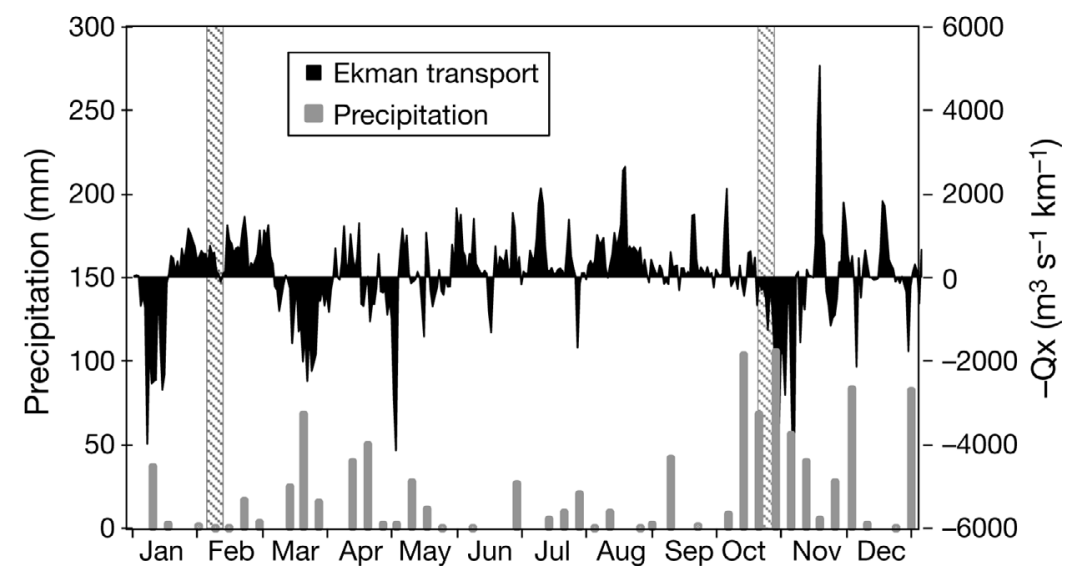

Fig. 2. Seasonal evolution of offshore Ekman transport (-Qx) and precipitation in 2005 . The 2 patterned vertical lines indicate the sampling periods 
addition, the mean river flow during the $10 \mathrm{~d}$ previous to the October cruise was as high as $42.6 \mathrm{~m}^{3} \mathrm{~s}^{-1}$.

\section{Hydrography}

The vertical sections of salinity and temperature for the 2 cruises (February off the river Miño, October off the Ría de Vigo) are shown in Fig. 3. In February, the IPC can be easily traced in the vertical section by its high salinity core (>35.85) from the surface to $\sim 150 \mathrm{~m}$ depth (Fig. 3A). Eastern North Atlantic Central Water (ENACW; salinity 35.69 , temperature $12.3^{\circ} \mathrm{C}$ ) was observed over the shelf as a result of the strong and prolonged upwelling period that occurred in the region during the month previous to the cruise (Fig. 2). In October, the IPC was located between 50 and $150 \mathrm{~m}$. A surface layer of water with salinity $<35.8$ was observed over the IPC, even at the outermost station (Fig. 3C). This low-salinity lens of freshwater origin could have been advected offshore in the previous period of northerly/relaxed winds, which favor positive Ekman transport. The downward trend of the isohalines and isotherms indicate a downwelling situation in October.

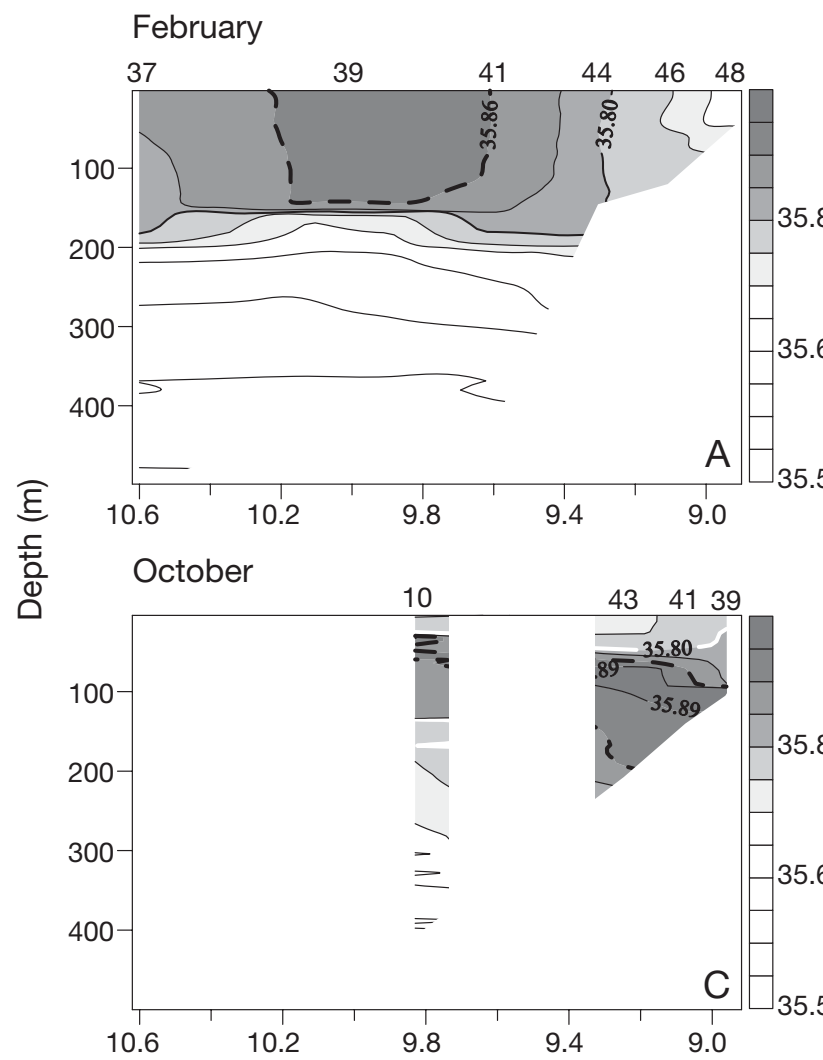

\section{Vertical distribution of microbial plankton}

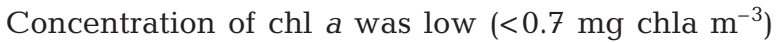
during both February and October (Fig. 4A,E), although the spatial and vertical distribution differed between periods. In October, the downward trend of the isolines toward the coast (Fig. 4E) reflected the downwelling situation, and the chl a concentration was higher close to the coast than offshore. The $<5 \mu \mathrm{m}$ phytoplankton (pico- and nanophytoplankton) distribution showed a similar pattern during both periods, with a higher contribution of $<5 \mu \mathrm{m}$ cells to total chl a concentration towards the ocean and values around 50 to $60 \%$ close to the coast (Fig. 4B,F). The abundance of the cyanophycean Synechococcus (Fig. 4C,G) increased offshore in February and clearly reflected downwelling in October. Higher Synechococcus abundances were observed in October, with mean values of $1.7 \times 10^{4}$ cells $\mathrm{cm}^{-3}$. In February, very low abundances $\left(<0.5 \times 10^{4}\right.$ cells $\left.\mathrm{cm}^{-3}\right)$ were observed at the coastal stations. The spatial and vertical distribution of bacteria, as determined by total DAPI counts (Fig. 4D,H), was very similar to that of chl $a$, although their abundance was consid-
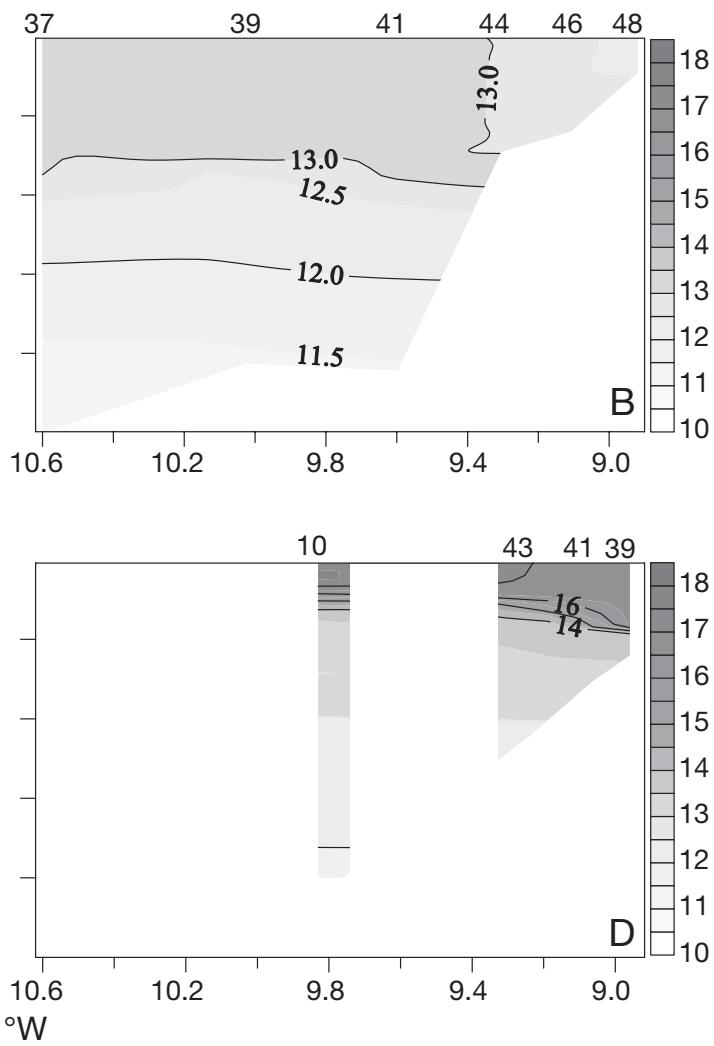

Fig. 3. Vertical distribution of $(\mathrm{A}, \mathrm{C})$ salinity and $(\mathrm{B}, \mathrm{D})$ temperature $\left({ }^{\circ} \mathrm{C}\right)$ along a transect perpendicular to the coast in $(\mathrm{A}, \mathrm{B})$ February and $(C, D)$ October. The thick white line in $(C)$ outlines the Western Iberian Buoyant Plume (defined by salinities $<35.8$ ), the dashed lines in $(A, C)$ outline the core of the Iberian Poleward Current (defined by salinities >35.85). Numbers on top of graph indicate sampling stations (see Fig. 1 for locations) 

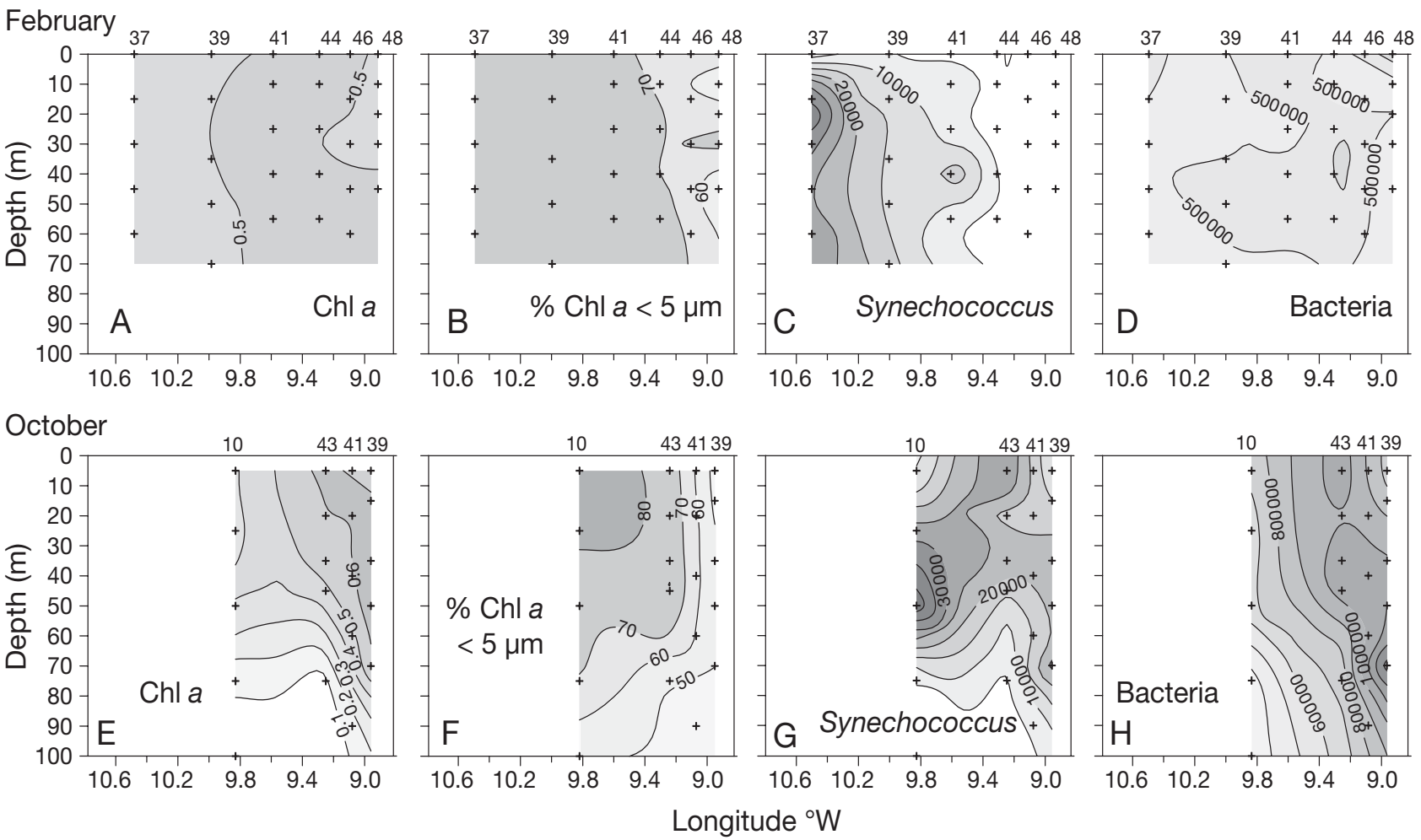

Fig. 4. Vertical distribution of $(\mathrm{A}, \mathrm{E})$ chlorophyll a $\left(\mathrm{chl}\right.$ a) concentration $\left(\mathrm{mg} \mathrm{m}^{-3}\right),(\mathrm{B}, \mathrm{F})$ percentage of chl a $<5 \mu \mathrm{m},(\mathrm{C}, \mathrm{G})$ Synechococcus abundance (cells $\mathrm{cm}^{-3}$ ) and $(\mathrm{D}, \mathrm{H})$ prokaryotic abundance $\left(\mathrm{cells} \mathrm{cm}^{-3}\right)$ along a transect perpendicular to the coast in (A-D) February and (E-H) October. +: sampling depths. Numbers on top of graph indicate sampling stations (see Fig. 1 for locations)

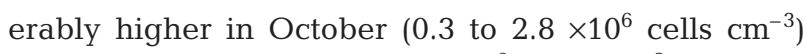
than in February $\left(0.3\right.$ to $0.6 \times 10^{6}$ cells $\left.\mathrm{cm}^{-3}\right)$.

\section{Bacterial community composition}

The composition of the bacterial assemblage showed remarkable differences between the 2 sampling periods (Fig. 5). The percentage of DAPIstained cells detected by the EUB338 probe averaged $63 \%$ (ranging from 33 to $95 \%$ ). The probes targeting Alpha-, Beta-, Gammaproteobacteria and Bacteroidetes identified between 14 and $68 \%$ of the total EUB338-positives, averaging $32 \%$ in February and $45 \%$ in October. Therefore, a considerable fraction of bacteria remained unidentified with this set of probes, especially in the IPC domain in February and at Stn 10 in October. In general, the relative abundance of all groups decreased from the coast to the ocean. The minimum detection rates for all groups were associated with the IPC. The most abundant groups during both cruises were Alphaproteobacteria and Bacteroidetes, contributing up to $20 \%$ (Alphaproteobacteria, Fig. $5 \mathrm{~A}, \mathrm{E}$ ) and $24 \%$ (Bacteroidetes, Fig. $5 \mathrm{D}, \mathrm{H})$ to the total prokaryotic abundance. Both groups showed similar relative abundances and dis- tribution during both periods. By contrast, the relative abundance of Beta- and Gammaproteobacteria was considerable higher in October than in February. Betaproteobacteria were mostly below the detection limit $(<0.5 \%$ of DAPI-stained cells) in February and reached values of ca. $2 \%$ of total DAPI-stained cells in October (Fig. 5B,F). The highest abundance of Betaproteobacteria (4.6\% of DAPI-stained cells) was found in October at Stn 26, off the river Miño (not shown in Fig. 5). The Gammaproteobacteria showed maximum relative abundances close to the coast in October (up to $14 \%$ ), whilst their relative abundance ranged only between 1 to $3 \%$ in February (Fig. 5C,G).

\section{Vertical distribution of microbial plankton metabolic rates}

PPP rates decreased with increasing depth during both sampling periods (Fig. 6A,E). Near-surface PPP rates ranged from 0.2 to $1.6 \mathrm{mg} \mathrm{C} \mathrm{m}^{-3} \mathrm{~h}^{-1}$ and did not significantly differ between sampling periods ( $t$-test, $\mathrm{p}$ $=0.74)$. DPP rates did not follow a clear trend with depth, and the highest rates $\left(>1 \mathrm{mg} \mathrm{C} \mathrm{m}^{-3} \mathrm{~h}^{-1}\right)$ were measured either in surface or in subsurface waters in 

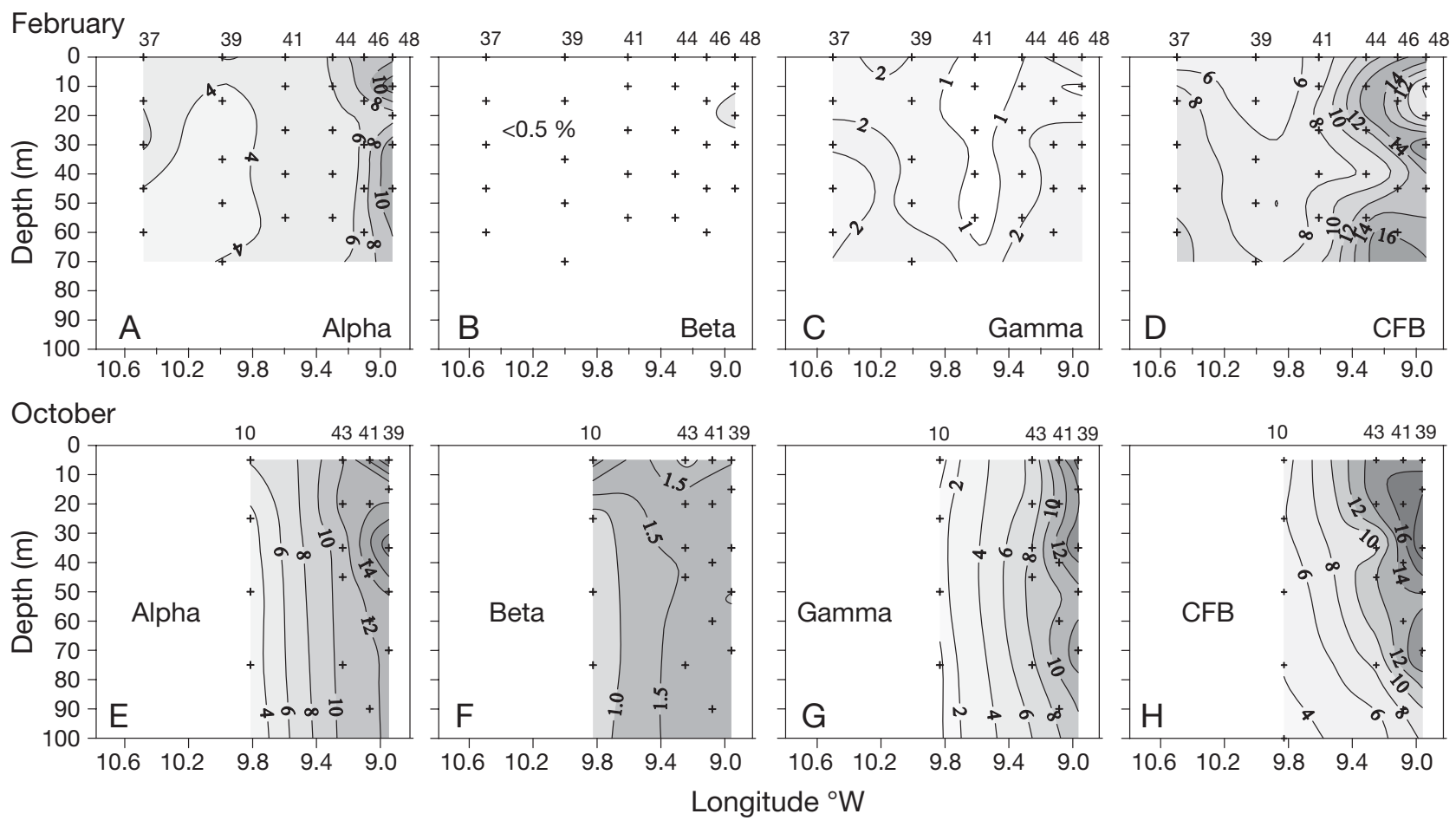

Fig. 5. Vertical distribution of the relative abundance of (A,E) Alphaproteobacteria (Alpha), (B,F) Betaproteobacteria (Beta), $(\mathrm{C}, \mathrm{G})$ Gammaproteobacteria (Gamma) and (D,H) Bacteroidetes (CFB), all in \% of DAPI-counts, along a transect perpendicular to the coast in February $(\mathrm{A}-\mathrm{D})$ and October $(\mathrm{E}-\mathrm{H})$. +: sampling depths. Numbers on top of graph indicate sampling stations (see Fig. 1 for locations)

February (Fig. 6B,F). DPP rates did not significantly differ between both sampling periods ( $t$-test, $\mathrm{p}=$ 0.177). By contrast, BP (Fig. 6C,G) and CR (Fig. 6D,H) were significantly higher in October than in February $(t$-test, $\mathrm{p}<0.001)$. BP was $8 \times$ and CR $3 \times$ higher in October than in February.
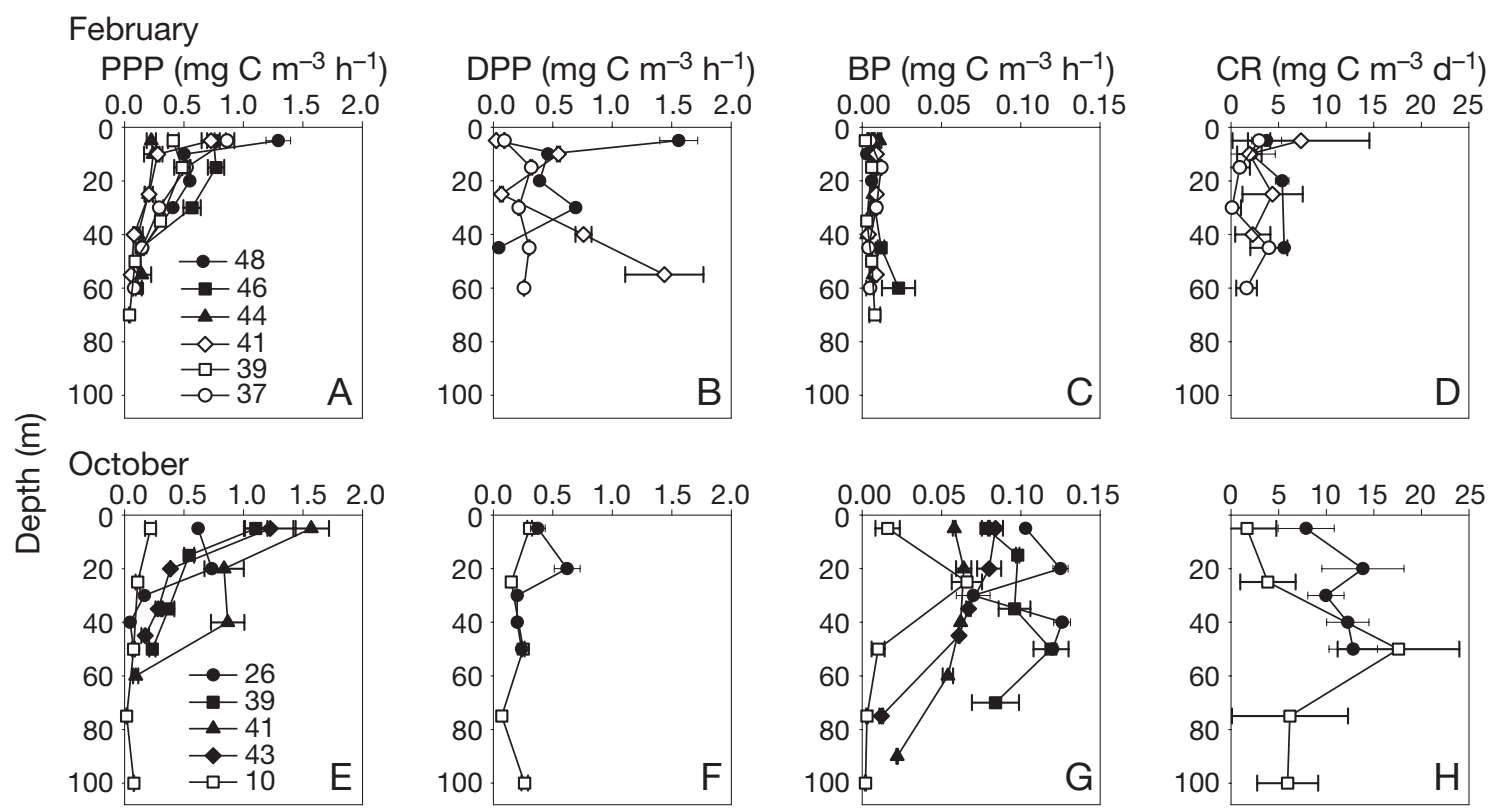

Fig. 6. Vertical profiles of $(A, E)$ particulate primary production $(P P P),(B, F)$ dissolved primary production $(D P P),(C, G)$ bacterial production $(\mathrm{BP})$ and $(\mathrm{D}, \mathrm{H})$ microbial community respiration $(\mathrm{CR})$ in $(\mathrm{A}-\mathrm{D})$ February and $(\mathrm{E}-\mathrm{H})$ October at the different sampling stations (means $\pm \mathrm{SE}$ ). See Fig. 1 for location of the sampling stations 


\section{Biogenic carbon fluxes through the microbial community}

The results allowed us to construct carbon budgets for 2 contrasting scenarios defined in the coastal transition zone off the northwest Iberian peninsula (Fig. 7), including a dry period (February 2005) and a rainy period (October 2005). We used only those stations where all fluxes were measured (Table 1). All variables are integrated for the euphotic layer and expressed in mg C m${ }^{-2}$ (for biomass) and $\mathrm{mg} \mathrm{C} \mathrm{m}^{-2} \mathrm{~d}^{-1}$ (for rates) (Table 1, Fig. 7A). The biomass and size structure of phytoplankton was very similar during February and October, with a higher importance of pico- and nanophytoplankton $(<5 \mu \mathrm{m})$ in February $(71 \%)$ than in
October $(63 \%)$. The magnitude of integrated total primary production (PPP plus DPP) was low (349 and 386 mg C m ${ }^{-2} \mathrm{~d}^{-1}$ in February and October, respectively) and similar for both sampling periods. Similarly, euphotic zone-integrated DPP did not differ between the 2 contrasting scenarios. By contrast, BB was about twice as high in October as in February. The differences in microbial plankton heterotrophic fluxes were even more remarkable. Integrated microbial community respiration was $4 \times$ higher in October (936 mg C $\mathrm{m}^{-2} \mathrm{~d}^{-1}$ ) than in February $\left(226 \mathrm{mg} \mathrm{C} \mathrm{m}^{-2} \mathrm{~d}^{-1}\right.$ ). A net heterotrophic metabolism was thus measured in October, whilst the production-to-respiration balance was positive in February. Bacterial carbon demand was $3.7 \times$ higher in October than in February. While concurrent
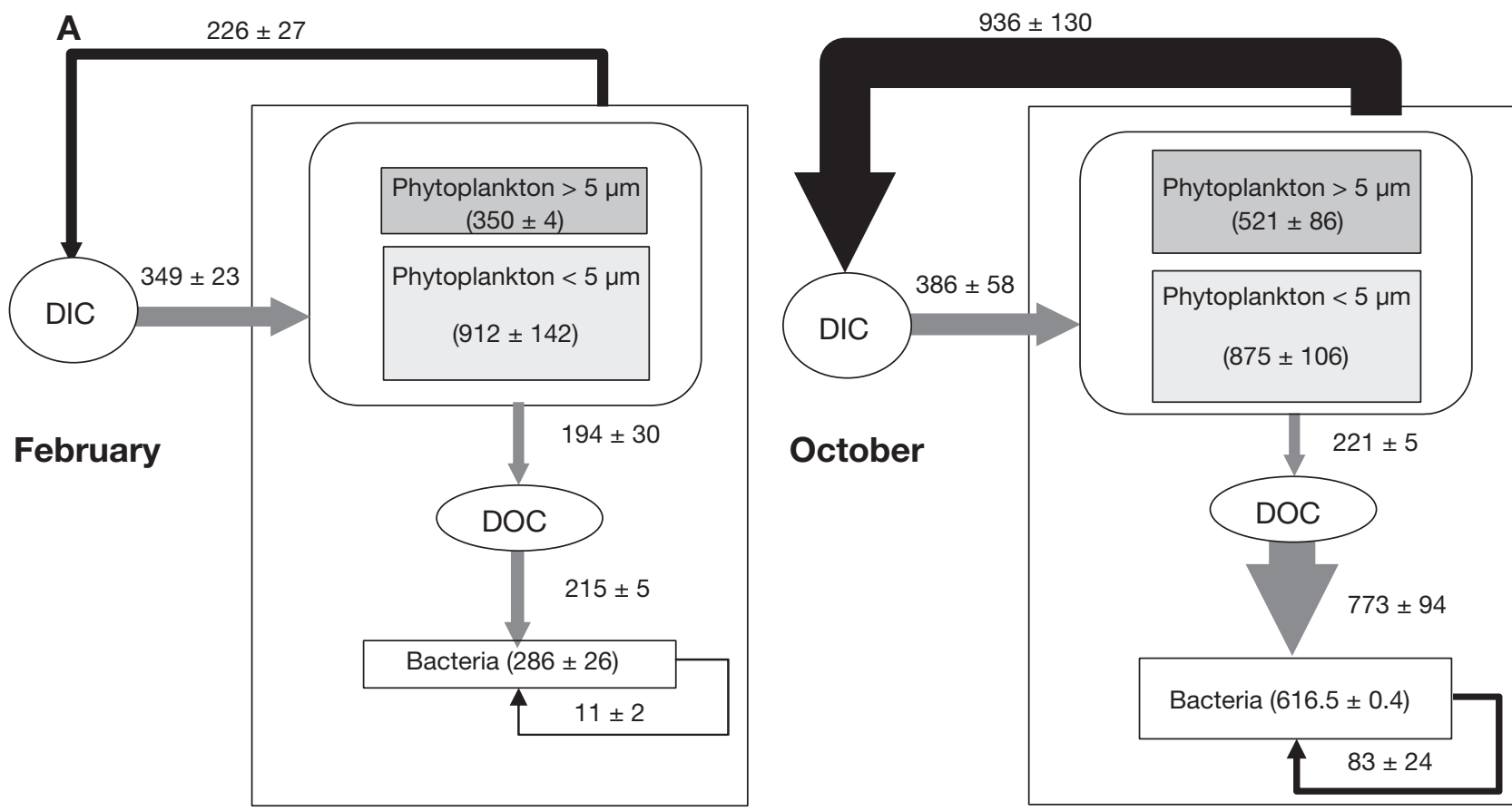

B

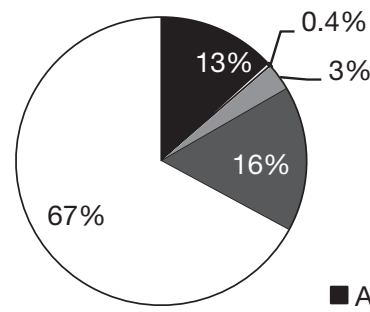

Alpha $\square$ Beta $\square$ Gamma $\square$ CFB $\square$ N.I.

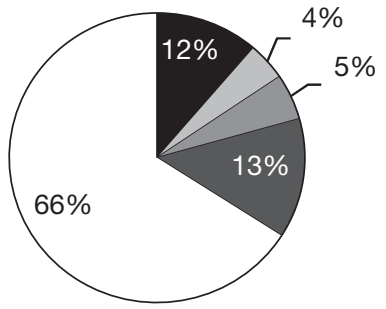

Fig. 7. (A) Averaged carbon budgets for the 2 scenarios found in the northwest Iberian coastal transition zone during the low productivity season: February (dry period) and October (rainy period). Values are means $\left( \pm \mathrm{SE}\right.$ ) for standing stocks $\left(\mathrm{mg} \mathrm{C} \mathrm{m}^{-2}\right.$ ) and rates $\left(\mathrm{mg} \mathrm{C} \mathrm{m}^{-2} \mathrm{~d}^{-1}\right)$. Boxes indicate standing stocks of different microbial compartments, arrows represent the carbon fluxes through compartments. DIC: dissolved inorganic carbon; DOC: dissolved organic carbon. Data from Table 1. Calculations and conversion factors are explained in 'Materials and methods'. (B) Bacterial community composition in February and October. Relative abundances are expressed as \% of total Eub338-positive cells. Alpha: Alphaproteobacteria; Beta: Betaproteobacteria; Gamma: Gammaproteobacteria; CFB: Bacteroidetes; N.I.: unidentified bacteria 
Table 1. Euphotic zone-integrated ( \pm propagated error) total primary production (TPP), dissolved primary production (DPP), bacterial production (BP), bacterial respiration (BR), community respiration $(\mathrm{CR}),<$ and $>5 \mu \mathrm{m}$ phytoplankton biomass $(\mathrm{PB})$, bacterial biomass $(\mathrm{BB})$, and depth-averaged $( \pm \mathrm{SE})$ relative abundance of Alphaproteobacteria (Alpha), Betaproteobacteria (Beta), Gammaproteobacteria (Gamma), and Bacteroidetes (CFB), at the intensive sampling stations. BR was estimated using the empirical model by Robinson (2008). \% EUB: percentage of total bacteria detected with the EUB338 probe

\begin{tabular}{|c|c|c|c|c|c|}
\hline \multirow[b]{2}{*}{ Variable } & \multirow[b]{2}{*}{ Stn 48} & \multirow{2}{*}{$\begin{array}{l}\text { February } \\
\text { Stn } 41\end{array}$} & \multirow[b]{2}{*}{ Stn 37} & \multicolumn{2}{|c|}{ October } \\
\hline & & & & Stn 26 & Stn 10 \\
\hline \multicolumn{6}{|c|}{ Productivity (mg C m ${ }^{-2} \mathrm{~d}^{-1}$ ) } \\
\hline TPP & $400 \pm 16$ & $346 \pm 30$ & $302 \pm 11$ & $468 \pm 14$ & $304 \pm 11$ \\
\hline DPP & $208 \pm 10$ & $249 \pm 28$ & $125 \pm 2$ & $227 \pm 14$ & $214 \pm 7$ \\
\hline $\mathrm{BP}$ & $15 \pm 2$ & $9 \pm 1$ & $10 \pm 1$ & $118 \pm 4$ & $48 \pm 7$ \\
\hline $\mathrm{BR}$ & $209 \pm 11$ & $192 \pm 10$ & $209 \pm 7$ & $819 \pm 34$ & $561 \pm 23$ \\
\hline $\mathrm{CR}$ & $260 \pm 45$ & $258 \pm 150$ & $160 \pm 80$ & $752 \pm 136$ & $1120 \pm 474$ \\
\hline \multicolumn{6}{|c|}{ Biomass (mg C m $\mathbf{~}^{-2}$ ) } \\
\hline$<5 \mu \mathrm{m}$ PB & 584 & 1178 & 973 & 724 & 1025 \\
\hline$>5 \mu \mathrm{m}$ PB & 358 & 352 & 342 & 642 & 399 \\
\hline BB & $223 \pm 8$ & $311 \pm 11$ & $323 \pm 11$ & $617 \pm 22$ & $616 \pm 22$ \\
\hline \multicolumn{6}{|c|}{ Relative bacterial abundances (\% EUB) } \\
\hline Alpha & $20 \pm 5$ & $11 \pm 1$ & $8 \pm 1$ & $16 \pm 1$ & $7 \pm 1$ \\
\hline Beta & $0.6 \pm 0.2$ & $0.3 \pm 0.1$ & $0.3 \pm 0.1$ & $6.4 \pm 0.6$ & $2.1 \pm 0.7$ \\
\hline Gamma & $4.3 \pm 0.8$ & $1.6 \pm 0.2$ & $3.1 \pm 0.2$ & $8 \pm 2$ & $1.8 \pm 0.3$ \\
\hline CFB & $21 \pm 2$ & $12 \pm 1$ & $16 \pm 3$ & $18 \pm 3$ & $8 \pm 1$ \\
\hline
\end{tabular}

(from June to October), and contributing 0 to $30 \%$ to total picophytoplankton over the rest of the year. Similarly, the contribution of Synechococcus biomass to total pico- and nanophytoplankton biomass in the present study was higher in October (on average 18\%) than in February (8\%). Unfortunately, we lack estimates of Prochlorococcus abundance. The vertical distribution of Synechococcus abundance (Fig. 4C,G) shows a clear association of this group with the IPCs domain, showing maximum numbers $\left(>2 \times 10^{4}\right.$ cell $\left.\mathrm{cm}^{-3}\right)$ in the frontal zones between the IPCs and open ocean waters (February, Fig. 4C) and the low salinity layer (October, Fig. 4G). A similar mean abundance and association with the IPCs was also reported by Calvo-Díaz et al. (2004) along the northern Iberian continental margin.

Despite the size structure of phytoplankton not differing greatly between both sampling periods, the bacterial community composition did show con-

DPP met bacterial carbon requirements in February, a bacterial carbon demand of $773 \mathrm{mg} \mathrm{C} \mathrm{m}^{-2} \mathrm{~d}^{-1}$, clearly exceeding the concurrent DPP of $221 \mathrm{mg} \mathrm{C} \mathrm{m}^{-2} \mathrm{~d}^{-1}$, was found in October. BP was $7.3 \times$ higher in October (83 $\mathrm{mg} \mathrm{C} \mathrm{m}^{-2} \mathrm{~d}^{-1}$ ) than in February $\left(11 \mathrm{mg} \mathrm{C} \mathrm{m}^{-2} \mathrm{~d}^{-1}\right)$.

The noticeable differences in bacterial carbon fluxes were accompanied by a change in the bacterial community composition (Fig. 7B), manifested by a higher contribution of Beta- and Gammaproteobacteria in October than in February.

\section{DISCUSSION}

\section{Microbial community structure in the CTZ during the downwelling season}

PB was dominated by small cells (pico- and nanophytoplankton), especially at offshore stations. In terms of chl $a$, the $<5 \mu \mathrm{m}$ fraction always contributed $>50 \%$. Previous studies in the same region also reported a dominance of small phytoplankton associated with low chl a concentrations $\left(<1 \mathrm{mg}\right.$ chla $\left.\mathrm{m}^{-3}\right)$ during late summer and autumn (Teira et al. 2001, Lorenzo et al. 2005). A recent study by Calvo-Díaz \& Morán (2006) in shelf waters of the southern Bay of Biscay showed a marked seasonality for picophytoplankton, with Cyanobacteria (both Synechococcus and Prochlorococcus) contributing 30 to $50 \%$ to total picophytoplankton biomass in nutrient-depleted waters siderable differences, apparently associated with the presence of lower salinity waters in October. The Betaproteobacteria group, which is typical for freshwater environments, is rare in marine waters, but can be found in estuarine and coastal waters with freshwater influence (Methé et al. 1998). Therefore, the presence of these bacteria in surface oceanic waters can be regarded as an indicator of freshwater inputs. In October, $2.12 \pm 0.41 \%$ of DAPI-stained cells were Betaproteobacteria, representing 2 to $9 \%$ of total EUB338-positive cells, compared with the undetectable levels $(0.22$ $\pm 0.07 \%$ of DAPI-stained cells) found in February. Garneau et al. (2006) also found a significant contribution of Betaproteobacteria (6\% of DAPI-counts) in a riverinfluenced offshore coastal Arctic station. Similarly, the relative contribution of Betaproteobacteria to total EUB338-positive cell abundances in the western Arctic Ocean ranged from 2.4 to $6.5 \%$ (Elifantz et al. 2007). The Gammaproteobacteria presented a higher relative abundance in October than in February. This group of bacteria is usually present in coastal waters at very low abundances and tends to bloom in response to episodic alterations, such as allochthonous matter input (Teira et al. 2008 and references therein). It is important to mention the relatively high percentage of detected bacteria that were not identified with the set of 4 probes we used (32 to $86 \%$ ). Similar percentages of undetected bacteria were reported by Alonso-Sáez et al. (2007) during autumn and winter months in Blanes Bay (Mediterranean Sea). Clone libraries consistently 
reveal that most bacteria fall within one of these 4 groups. The unidentified bacteria could correspond to bacteria showing extremely low activity levels, which could limit the detection with CARD-FISH. On the other hand, the high percentage of unidentified bacteria could also reflect poor coverage of the probes (Amann \& Fuchs 2008).

\section{Carbon budgets in the CTZ during the downwelling season}

Both phytoplankton and bacterial standing stocks were within the range of previously reported values for the region (Barbosa et al. 2001, Teira et al. 2001, Morán et al. 2002). The magnitude of primary production (PPP and DPP) and BP as well as microbial $\mathrm{CR}$ are also in agreement with previous studies in the region (Teira et al. 2001, Barbosa et al. 2001, Morán et al. 2002). The empirical leucine-to-carbon conver-

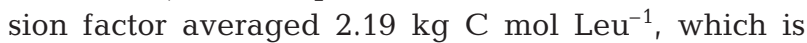
higher that the mean value reported by Barbosa et al. (2001) in the same region during the upwelling season. However, it is within the range of values reported by Morán et al. (2002) for the same region during late summer, and is considerably lower than the empirical factor determined by Valencia et al. (2003) in nearby shelf waters off A Coruña (northwestern Spain).

Despite the rates of primary production did not sensibly change between sampling periods, the rates of both bacterial production and microbial respiration were up to 8 times higher in October than in February (Fig. 6), so that net heterotrophy was measured in October, whereas a net autotrophic production to respiration balance was found in February (Fig. 7). To our knowledge, our study was the first measuring PPP and DPP, BP and microbial plankton CR simultaneously in this area, which allowed us to construct a more complete carbon budget than that previously constructed by Teira et al. (2001). These authors built a similar carbon budget for shelf/shelf-break waters in October 1999, although they did not include bacterial carbon fluxes. The comparison between bacterial carbon requirements and concurrent rates of DPP provide a good indication of the degree of coupling between phytoplankton and bacteria. A bacterial carbon demand exceeding concurrent primary production could only be sustained by allochthonous or previously accumulated autochthonous organic matter.

The main factors regulating bacterial processes in aquatic systems are temperature and both organic and inorganic substrate supply (bottom-up factors). Bacterial growth can also be controlled by top-down factors such as bacterivory and viral lysis, though we lack information about the magnitude of any of those processes during the sampling periods of the present study. Notwithstanding, the strong and significant relationship between $\mathrm{BB}$ and $\mathrm{BP}$ for the whole area $\left(\mathrm{r}^{2}=0.73, \mathrm{p}<0.001, \mathrm{n}=50\right)$ would indicate that $\mathrm{BB}$ was controlled by resources, rather than by predation (Billen et al. 1990, Ducklow \& Carlson 1992).

The mean temperature in the euphotic layer was $3.5^{\circ} \mathrm{C}$ higher in October than in February. Using the averaged euphotic zone-integrated data shown in Fig. 7, we analyzed to what extent bacterial growth could be controlled by temperature. Bacterial growth was approximated as BP/BB. Considering the averaged bacterial growth measured in February $\left(0.094 \mathrm{~d}^{-1}\right)$ and applying a $\mathrm{Q}_{10}$ value ranging from 2 to 3.3 (Barbosa et al. 2001, Vázquez-Domínguez et al. 2007), we predicted the bacterial growth in October to be 0.119 to $0.143 \mathrm{~d}^{-1}$. The actual bacterial growth of $0.263 \mathrm{~d}^{-1}$ measured in October was about $2 \times$ higher than the rates expected from the temperature increment.

Regarding inorganic nutrients, average nitrate concentration within the euphotic zone was 1.6 and $4.6 \mu \mathrm{M}$ during October and February, respectively (Alvarez-Salgado pers. obs.), suggesting no N-limitation in February. The same holds for phosphate, with mean values of 0.13 and $0.3 \mu \mathrm{M}$ during October and February, respectively (Álvarez-Salgado pers obs.). Our data strongly suggest that bacterial growth was mainly controlled by organic substrates.

We used the empirical model by Robinson (2008) to estimate BR from BP because it predicts values of BR midway between those derived from previous models (del Giorgio \& Cole 2000, Rivkin \& Legendre 2001). The total bacterial carbon demand in February and October was 215 and $773 \mathrm{mg} \mathrm{C} \mathrm{m} \mathrm{C} \mathrm{d}^{-1}$, respectively, giving bacterial growth efficiencies (BGE) of 0.05 and 0.11 , respectively. The derived BGE values are within the range of those previously reported BGE for coastal waters (Robinson 2008), indicating that our BCD estimates are not severely over- or underestimated. In February, DPP would be high enough $(194 \pm 30 \mathrm{mg}$ C $\mathrm{m}^{-2} \mathrm{~d}^{-1}$ ) to meet the estimated bacterial carbon requirements (Fig. 7A), which agrees with the results obtained by Barbosa et al. (2001) during summer upwelling. Conversely, the DOC production derived from phytoplankton would be not enough to fulfill the calculated carbon demand by bacteria in October (Fig. 7A). Concurrent DPP would be sufficient to support total bacterial carbon consumption only if an unrealistically high BGE (>0.38) is assumed. A similar discrepancy was reported by Morán et al. (2002) for the same region during spring and late summer and by Teira et al. (2003) in a nearby area (off A Coruña) in May and September 1999. 
DOC concentration in the euphotic layer was, on average, higher in October $(72 \mu \mathrm{M})$ than in February $(58 \mu \mathrm{M})$ (Álvarez-Salgado pers. obs.). Possible sources for the 'extra' carbon sustaining heterotrophic metabolism in October include: (1) DOC accumulated during the productive season in the Rías Baixas that is subsequently exported horizontally across the shelf, and (2) the input of DOC through riverine discharge and continental runoff. The origin of these organic substrates remains to be discussed, but there is some evidence for an influence of continental inputs. Álvarez-Salgado et al. (1999) concluded that the Rías Baixas operate as sources of biodegradable dissolved organic matter (DOM) for the adjacent shelf waters. On the other hand, Doval et al. (1997) reported that, during the downwelling season, the surface DOM excess in the Ría de Vigo is due to freshwater contribution. Gago et al. (2005) have recently analyzed the chemical composition of continental materials entering the inner Ría de Vigo. These authors found that most of the organic carbon, nitrogen and phosphorous occurred in dissolved form, and that the chemical composition of the organic materials was compatible with detrital organic matter derived from aquatic plants or soil-leaching. The abnormally high precipitation in the weeks both before and during the cruise, together with the wind patterns, could explain the offshore extension of freshwater that was observed as a low-salinity lens over the IPC during the October cruise.

Several studies have suggested the role of continental inputs as potential sources of allochthonous matter in sustaining net heterotrophy in coastal areas (e.g. Sempéré et al. 2000, Chen et al. 2003, Reinthaler \& Herndl 2005, La Ferla et al. 2006). Teira et al. (2001) suggested a heterotrophic balance for the microbial community under similar conditions of downwelling and freshwater influence (October 1999) in the region examined in the present study. The authors argued that the phytoplankton community structure strongly influences the metabolic balance of the microbial community. Consequently, planktonic food webs based mainly on picophytoplankton would be more prone to heterotrophy in the event of an allochthonous supply of organic matter. In the present study, we found an autotrophic community dominated by picophytoplankton during both sampling periods; however, the microbial community metabolism was net autotrophic in February and net heterotrophic in October, when the system appeared to be more affected by inputs of allochthonous matter. The intense precipitation, the hydrography, and the significant presence of Betaproteobacteria, typical for freshwater systems, during October strongly support the influence of continental inputs of matter in this coastal transition zone.
Acknowledgements. We thank all the people involved in the project ZOTRACOS who helped with the preparation and sampling during the 2 cruises, particularly the principal investigator R. Varela. We are indebted to the GOFUVI research group (University of Vigo) who provided the CTD data. Special thanks to M. Cabanas, and X. A. ÁlvarezSalgado who provided meteorological and nutrient data. We also thank the captain and crew on board the RV 'Cornide de Saavedra'. This research was supported by the CICyT contract ZOTRACOS (REN2003-06633). E.T. was funded by a European Community Marie Curie Reintegration Fellowship (MERG-CT-2004-511937) and a Juan de la Cierva-MEC contract.

\section{LITERATURE CITED}

Alderkamp AC, Sintes E, Herndl GJ (2006) Abundance and activity of major groups of prokaryotic plankton in the coastal North Sea during spring and summer. Aquat Microb Ecol 45:237-246

Alonso C, Warnecke F, Amann R, Pernthaler J (2007) High local and global diversity of Flavobacteria in marine plankton. Environ Microbiol 9:1253-1266

Alonso-Sáez L, Balagué V, Sà EL, Sánchez O and others (2007) Seasonality in bacterial diversity in north-west Mediterranean coastal waters:assessment through clone libraries, fingerprinting and FISH. FEMS Microbiol Ecol 60:98-112

Álvarez I, deCastro M, Gómez-Gesteira M, Prego R (2006) Hydrographic behaviour of the Galician Rías baixas (NW Spain) under the spring intrusion of the Miño River. J Mar Syst 60:144-152

Álvarez-Salgado XA, Doval MD, Pérez FF (1999) Disolved organic matter in shelf waters off the Ría de Vigo (NW Iberian upwelling system). J Mar Syst 18:383-394

Álvarez-Salgado XA, Beloso S, Joint I, Nogueira E and others (2002) New production of the NW Iberian shelf during the upwelling season over the period 1982-1999. Deep-Sea Res I 49:1725-1739

Álvarez-Salgado XA, Figueiras FG, Pérez FF, Groom S and others (2003) The Portugal coastal counter current off NW Spain: new insights on its biogeochemical variability. Prog Oceanogr 56:281-321

Amann R, Fuchs BM (2008) Single-cell identification in microbial communities by improved fluorescence in situ hybridization techniques. Nat Rev Microbiol 6:339-348

> Barbosa AB, Galvão HM, Mendes PA, Álvarez-Salgado X, Figueiras FG, Joint I (2001) Short-term variability of heterotrophic bacterioplankton during upwelling off the NW Iberian margin. Prog Oceanogr 51:339-359

Barlow RG, Mantoura RF, Cummings DG, Pond DW, Harris RP (1998) Evolution of phytoplankton pigments in mesocosm experiments. Estuar Coast Shelf Sci 46:15-22

Billen G, Servais P, Becquevort S (1990) Dynamics of bacterioplankton in oligotrophic and eutrophic aquatic environments: bottom-up or top-down control? Arch Hydrobiol 207:37-42

Bjørnsen PK, Kuparinen J (1991) Determination of bacterioplankton biomass, net production and growth efficiency in the Southern Ocean. Mar Ecol Prog Ser 71: 185-194

Calvo-Díaz A, Morán XAG (2006) Seasonal dynamics of picoplankton in shelf waters of the southern Bay of Biscay. Aquat Microb Ecol 42:159-174

Calvo-Díaz A, Morán XAG, Nogueira E, Bode A, Varela M (2004) Picoplankton community structure along the north- 
ern Iberian continental margin in late winter-early spring. J Plankton Res 26:1069-1081

Castro CG, Álvarez-Salgado XA, Figueiras FG, Pérez FF, Fraga F (1997) Transient hydrographic and chemical conditions affecting microplankton populations in the coastal transition zone of the Iberian upwelling system (NW Spain) in September 1986. J Mar Res 55:321-352

Chen CC, Shiah FK, Gong GC, Chiang KP (2003) Planktonic community respiration in the East China Sea: importance of microbial consumption of organic carbon. Deep-Sea Res II 50:1311-1325

del Giorgio PA, Cole JJ (2000) Bacterial energetics and growth efficiency. In: Kirchman DL (ed) Microbial ecology of the oceans. Wiley-Liss, New York, p 289-326

> Doval MD, Álvarez-Salgado XA, Pérez FF (1997) Dissolved organic matter in a temperate embayment affected by coastal upwelling. Mar Ecol Prog Ser 157:21-37

Duarte CM, Prairie YT (2005) Prevalence of heterotrophy and atmospheric $\mathrm{CO}_{2}$ emissions from aquatic ecosystems. Ecosystems 8:862-870

Ducklow HW, Carlson CA (1992) Oceanic bacterial productivity. Adv Microb Ecol 12:113-181

- Elifantz H, Dittel AI, Cottrell MT, Kirchman DL (2007) Dissolved organic matter assimilation by heterotrophic bacterial groups in the western Arctic Ocean. Aquat Microb Ecol 50:39-49

Fukuda R, Ogawa H, Nagata T, Koike I (1998) Direct determination of carbon and nitrogen contents of natural bacterial assemblages in marine environments. Appl Environ Microbiol 64:3352-3358

Gago J, Álvarez-Salgado XA, Nieto-Cid M, Brea S, Piedracoba S (2005) Continental inputs of C, N, P and Si species to the Ría de Vigo (NW Spain). Estuar Coast Shelf Sci 65: 74-82

Garneau ME, Vincent WF, Alonso-Sáez L, Gratton Y, Lovejoy C (2006) Prokaryotic community structure and heterotrophic production in a river-influenced coastal artic ecosystem. Aquat Microb Ecol 42:27-40

Grasshoff K, Ehrhardt M, Kremling M (1983) Methods of seawater analysis, 2nd edn. Verlag Chemie, Weinheim

Hobbie JE (1988) A comparison of the ecology of planktonic bacteria in fresh and salt water. Limnol Oceanogr 33: 750-764

Kisand V, Andersson N, Wikner J (2005) Bacterial freshwater species successfully immigrate to the brackish water environment in the northern Baltic. Limnol Oceanogr 50: 945-956

La Ferla R, Azzaro M, Maimone G (2006) Microbial respiration and trophic regimes in the Northern Adriatic Sea (Mediterranean Sea). Estuar Coast Shelf Sci 69:196-204

Langenheder S, Kisand V, Lindström E, Wikner J, Tranvik L (2004) Growth dynamics within bacterial communities in riverine and estuarine batch cultures. Aquat Microb Ecol 37:137-148

Longhurst A (1995) Seasonal cycles of pelagic production and consumption. Prog Oceanogr 36:77-167

Lorenzo LM, Arbones B, Tilstone GH, Figueiras FG (2005) Across-shelf variability of phytoplankton composition, photosynthetic parameters and primary production in the NW Iberian upwelling system. J Mar Syst 54:157-173

Marañón E, Cermeño P, Fernández E, Rodríguez J, Zabala L (2004) Significance and mechanisms of photosynthetic production of dissolved organic carbon in a coastal eutrophic ecosystem. Limnol Oceanogr 49:1652-1666

Methé BA, Hiorns WD, Zehr JP (1998) Contrasts between marine and freshwater bacterial community composition: analyses of communities in Lake George and six other Adirondack lakes. Limnol Oceanogr 43:368-374
Morán XAG, Gasol JM, Pedrós-Alió C, Estrada M (2002) Partitioning of phytoplankton organic carbon production and bacterial production along a coastal-offshore gradient in the NE Atlantic during different hydrographic regimes. Aquat Microb Ecol 29:239-252

Nieto-Cid M, Álvarez-Salgado XA, Brea S, Pérez FF (2004) Cycling of dissolved and particulate carbohydrates in a coastal upwelling system (NW Iberian Peninsula). Mar Ecol Prog Ser 283:39-54

Nogueira E, Pérez FF, Ríos AF (1997) Seasonal patterns and long-term trends in an estuarine upwelling ecosystem (Ría de Vigo, NW Spain). Estuar Coast Shelf Sci 44:285-300

Peliz A, Rosa T, Santos AMP, Pissarra J (2002) Fronts, jets, and counter-flows in the Western Iberia Upwelling System. J Mar Syst 35:61-77

Pérez FF, Álvarez-Salgado XA, Rosón G, Ríos AF (1992) Carbonic-calcium system, nutrients and total organic nitrogen in continental runoff to the Galician Rías Baixas, NW Spain. Oceanol Acta 15:595-602

> Reinthaler T, Herndl GJ (2005) Seasonal dynamics of bacterial growth efficiencies in relation to phytoplankton in the Southern North Sea. Aquat Microb Ecol 39:7-16

Ríos AF, Nomble MA, Pérez FF, Rosón G, Fraga F (1992) Calculation of runoff to an estuary. Ría de Vigo. Sci Mar 56: 29-33

Rivkin RB, Legendre L (2001) Biogenic carbon cycling in the ocean: effects of microbial respiration. Science 291: $2398-2400$

Robinson C (2008) Heterotrophic bacteria respiration. In: Kirchman DL, Mitchell R (eds) Microbial ecology of the oceans. 2nd edition, Wiley-Liss, New York, p 299-334

Sandberg J, Andersson A, Johansson S, Wikner J (2004) Pelagic food web structure and carbon budget in three brackish water environments: potential importance of terrigenous carbon. Mar Ecol Prog Ser 268:13-29

> Sempéré R, Charrière B, Van Wambeke F, Cauwet G (2000) Carbon inputs of the Rhône River to the Mediterranean Sea: Biogeochemical implications. Global Biogeochem Cycles 14:669-681

Serret P, Fernández E, Sostres JA, Anadón R (1999) Seasonal compensation of microbial production and respiration in a temperate sea. Mar Ecol Prog Ser 187:43-57

Teira E, Serret P, Fernández E (2001) Phytoplankton sizestructure, particulate and disolved organic carbon production and oxygen fluxes through microbial communities in the NW Iberian coastal transition zone. Mar Ecol Prog Ser 219:65-83

Teira E, Abalde J, Álvarez-Ossorio MT, Bode A and others (2003) Plankton carbon budget in a coastal wind-driven upwelling station off A Coruña (NW Iberian Peninsula). Mar Ecol Prog Ser 265:31-43

Teira E, Gasol JM, Aranguren-Gassis M, Fernández A, González J, Lekunberri I, Álvarez-Salgado XA (2008) Linkages between bacterioplankton community composition, heterotrophic carbon cycling and environmental conditions in a highly dynamic coastal ecosystem. Environ Microbiol 10:906-917

Valencia J, Abalde J, Bode A, Cid A and others (2003) Variations in planktonic bacterial biomass and production, and phytoplankton blooms off A Coruña (NW Spain). Sci Mar 67:143-157

Varela RA, Rosón G, Herrera JL, Torres-López S, FernándezRomero A (2005) A general view of the hydrographic and dynamical patterns of the Rías Baixas adjacent sea area. J Mar Syst 54:97-113

> Vázquez-Domínguez E, Vaqué D, Gasol JM (2007) Ocean warming enhances respiration and carbon demand of 
coastal microbial plankton. Glob Change Biol 13: $1327-1334$

Wollast R (1993) Interactions of carbon and nitrogen cycles in the coastal zone. In: Wollast R, Mackenzie FT, Chou L (eds) Interactions of C, N, P and S. Biogeochemical cycles and global change, NATO ASI series I: Global environ-

Editorial responsibility: Rutger de Wit, Montpellier, France mental change, Vol. 4, Springer-Verlag, New York, Berlin, p 195-210

Worden AZ, Nolan JK, Palenik B (2004) Assessing the dynamics and ecology of marine picophytoplankton: the importance of the eukaryotic component. Limnol Oceanogr 49: 168-179

Submitted: June 19, 2008; Accepted: January 14, 2009

Proofs received from author(s): April 1, 2009 